Abstracta Iranica Iranica

Revue bibliographique pour le domaine irano-aryen

Volume 31 | 2011

Comptes rendus des publications de 2008

\title{
Love in Sufism: From Rabia to Ibn al-Farid. Istanbul, Insan, 2008, $251 \mathrm{p}$.
}

Ève Feuillebois-Piérunek

\section{Q OpenEdition}

1 Journals

Édition électronique

URL : http://journals.openedition.org/abstractairanica/39716

DOI : 10.4000/abstractairanica.39716

ISSN : 1961-960X

\section{Éditeur :}

CNRS (UMR 7528 Mondes iraniens et indiens), Éditions de l'IFRI

\section{Édition imprimée}

Date de publication : 15 mai 2011

ISSN : 0240-8910

\section{Référence électronique}

Ève Feuillebois-Piérunek, "Love in Sufism: From Rabia to Ibn al-Farid. Istanbul, Insan, 2008, 251 p. », Abstracta Iranica [En ligne], Volume 31 | 2011, document 241, mis en ligne le 11 octobre 2012, consulté le 29 septembre 2020. URL : http://journals.openedition.org/abstractairanica/39716 ; DOI : https:// doi.org/10.4000/abstractairanica.39716

Ce document a été généré automatiquement le 29 septembre 2020.

Tous droits réservés 


\title{
Love in Sufism: From Rabia to Ibn al- Farid. Istanbul, Insan, 2008, 251 p.
}

\author{
Ève Feuillebois-Piérunek
}

1 Ce livre étudie le thème de l'amour divin dans le soufisme, en particulier chez cinq personnalités importantes de ce mouvement : Rabī‘a, Ḥallāj, Ġazālī, Ibn 'Arabī et Ibn alFārid. Les deux premiers chapitres présentent le sujet de manière globale et ne manquent pas d'intérêt, même si les comparaisons maladroites avec le christianisme trahissent le manque de familiarité de l'A. avec les dogmes de la foi chrétienne.

2 Les autres chapitres, consacrés chacun à une figure soufie, possèdent tous la même structure interne : courte biographie de l'auteur insérée dans son contexte historique, social et culturel, l'amour de l'homme pour Dieu, l'amour de Dieu pour l'homme. Chaque auteur est caractérisé par une compréhension particulière de l'amour : l'amour pur et désintéressé de l'homme pour Dieu chez Rabīa, la création comme manifestation du Dieu-Amour et l'amour comme aspiration à l'union avec l'Essence divine chez Ḥallāj, l'amour comme fruit de la connaissance et recherche du plaisir chez Ġazālī pour qui l'amour de Dieu peut être acquis par l'effort de l'homme conjointement à la grâce divine, unicité de toutes les formes d'amour qui se rejoignent dans l'Amour de Dieu pour Lui-même chez Ibn 'Arabī, l'amour comme retour à Dieu, mort à soi et renaissance en l'Aimé chez Ibn al-Fārid.

3 C'est le premier ouvrage à s'intéresser au thème de l'amour chez autant d'auteurs différents et à tenter une synthèse sur ce sujet qui mérite encore d'être approfondi.

\section{INDEX}

Thèmes : 8 . Soufisme 
AUTEURS

ÈVE FEUILLEBOIS-PIÉRUNEK

Université Sorbonne Nouvelle - Paris 3 - Mondes iranien et indien 